Ayurlog: National Journal of Research in Ayurved Science

Website: http://www.ayurlog.com

Volume: $6^{\text {th }} \mid$ Issue: $7^{\text {th }} \mid$ Oct- Dec 2018

\title{
A review on mutra pariksha (urine examination) by Ayurvedic perspective.
}

\section{Sanjay G. Paikrao*1 ${ }^{1}$, Arun S. Dudhamal ${ }^{* 2}$}

1. Assistant Professor,

2. Associate Professor and HOD,

Dept. of Rognidan and Vikriti Vigyana, APM's Ayurved Mahavidyalaya,

Sion, Mumbai- 400022, Maharashtra

*Corresponding Author: drpaikrao@gmail.com 9922577551

\begin{abstract}
:
attempt has been made to elaborate the ayurvediya mutra pariksha collectively in respect to odor, color, quantity etc which can be a important diagnostic and prognostic tool.

and prognostic tool but in Ayurveda urine examination is used in a systematic and scientific way for knowing the diagnosi and prognosis of the disease from samhit kala. Thousands of year before, for diagnosis of the various aspects of the disease and diseased person several methods has been described in different Ayurved samhita. These methods can be broadly classified in to Rogi pariksha and Rog pariksha. While explaining the astavidha (Ashtasthan) pariksha Acharya Yogratnakar has described the methods examination of mutra pariksha after the explanation of the Nadi pariksha and Mala pariksha. He has also described the another important technique of the mutra parikha known as Tail bindu pariksha which is used for knowing the prognosis of the disease. Mutra pariksha as such in systematic way is not described in brihattrayi, scattered references are available in relation with the physiological and pathological state of sharir. Here

Key words: samhita kalin, ashtasthan pariksha, mutra pariksha, tail bindu pariksha.

\section{Introduction:}

Acharya charaka has rightly said that vaidya should study the various aspects of disease and disease person by rogi pariksha and rog parksha firstly and thereafter the treatment should be chosen accordingly ${ }^{[1]}$. The patient is the true element of the examination and patient should be examined to assess the life span of the patient and to assess the strength of the patient and to assess the strength of the morbid pathology of the doshas ${ }^{[2]}$.

Several types of the pariksha vidhies has been described by different acharyas in different samhita. Acharya Yogratnakar has described the Ashtasthan parikhsa vidhi. It is a one of the important
\end{abstract}


parikhsa which explains not only the methods of clinical examination but also some laboratory investigations. Beside this he has narrated a special technique of urine examination i.e. Tail Bindu Pariksha which is used to knowing the prognosis of the disease from samhita kala. Mutra pariksha is not described in brihattrayi systematically, scattered references are available in relation with purvarupa, rupa, updrava, arishta laxnas of different vyadhies and in description regarding the physiological state of the body. Hence this study endeavors to elaborate the mutra pariksha vidhi with an Ayurvedic perspective.

Aim: To Study the mutra pariksha vidhi with an Ayurvedic perspectives.

\section{Objectives:}

1. To evaluate the methods of mutr parkisha with an ayurved perspectives.

2. To elaborate the till bindu pariksha explained by the Yogratnakara.

1. To evaluation of the mutra pariksha as a diagnostic and prognostic tool.

\section{Material and Method:}

Conceptual and relevant references are taken from Ayurved samhita. After studying the related concepts, the efforts has been made for a conclusion which based on discussion.

\section{Literature review:}

Mala are the waste material that are excreted out of the body, it is a byproduct of the metabolic activities in the body. Mala are classified in to two i.e. Annamala and dhatu mala. Annamala are Purish,
Mutra, mal vayu, sweda ${ }^{[3]}$. Dhatu mala are formed during process of dhatupaka in which seven types of dhatwagni acts on the sara rasa and respective dhatues are formed along with their respective Dhatu mala. According to Charakacharya they are eight ${ }^{[4]}$ and according to Sharangdhar Samhita they are seven ${ }^{[5]}$. To perform a mutra pariksha vidhi shadvidha pariksha of sushruta (prashne, chakshu, sparsh, shrotra, ghran, rasana prakisha) can be applied $^{[6]}$.

\section{Formation of Mutra:}

Mala are formed in the large intestine. Jatharagni acts on the ahara dravya and then they are digested in to sara and kitta. Absorbable part is sara and non absorbable part is kitta. Seven types of jatharagni and panch mahabhutagni acts on the sara rasa and then respective types of dhatues are formed along with their respective hatumala. Non absorbable part of food material i.e. kitta from which the solid part is purisha is expelled out from the body by the purishvaha srotas. liquid part which is goes to the mutravaha srotas where it is called mutra. This concept of formation of sara and kitta from digested food after action of agni also applicable to dhatupaka ${ }^{[7]}$.

\section{Properties of Normal urine (Samanya mutra guna):}

Acharya charaka has told the predominance of the aap mahabutbhava in the urine. According to ashtangsangrahakara mutra is the seat of the kapha. Rasa of normal urine is kshara(alkaline), tikshna, lavana(salt) rasa $^{[8]}$ and resembles as a kupa jala (well water) [9] which have a clear and transparent appearance when there is a 
equilibrium of dosha and dhatu is present. Acharya sushruta while explaining prameh nivriti laxans has mentioned that anavilata(clean), appicchilata(non slimiy), visada(clear), tikta (bitter), katu(pungent) of mutra represents the arogya ${ }^{[10]}$. Mutra praman is four anjali ${ }^{[11]}$. Prabhuta mutrata is mentioned in prameha samanya laxanas $^{[12]}$ indicates the poly urea which has a diagnostic importance in prameha.

\section{Mutra Prashne pariksha:}

Vaidya must take proper history regarding micturation by friendly and caring attitude with patient. The complaint related to urination should be noted properly. Questions should be asked about urinary flow, vedana(pain) during urination, Avrodhajanaya mutrapravruti (obstruction in urinary flow), Mutra praman(volume), ahoratra and ratri vegsankhya (frequency), Naktamutrata(nocturnd polyurea), mutradaha and abnorme constituents in the urine etc. If there is previous or present history of ashmari, mutrakriccha, mautraghata, prameha, yon sankaramak roga etc should be taken in consideration.

\section{Mutra Chakshu Pariksha:}

Mutra should examine in the natural light after sunrise for appearance(bhasmodaka, gorochana, shankhchurnavata) varna, accha, avil, anavil,rakta puya, varna.

\section{Mutra pariksha for Dosha and doshaprakop:}

The normal appearance of the mutra is clear and transparent. It may be altered due to dosha prabhava, doshaprakopa and vyadhi vishesh ${ }^{[13]}$.

\begin{tabular}{|l|l|}
\hline $\begin{array}{l}\text { Dosha prabhava } \\
\text { on mutra }\end{array}$ & \multicolumn{1}{|c|}{ Mutra varnadi guna } \\
\hline Vata dosha & Pandur varna \\
\hline Pitta dosha & Rakta varna \\
\hline Kapha dosha & Safen \\
\hline Vat prakopa & Nilam, ruksha \\
\hline Pitta prakopa & Pita, aruna, tailasam \\
\hline Kapha prakopa & Snigdha, kamal jal tulya \\
\hline Rakta prakopa & Ushna, Rakta varna \\
\hline Pitt vata prakopa & $\begin{array}{l}\text { Dhumjalbh(dhum-mishrit } \\
\text { jal sam), ushna, }\end{array}$ \\
\hline $\begin{array}{l}\text { Vata kapha } \\
\text { prakopa }\end{array}$ & $\begin{array}{l}\text { Shwet } \\
\text { budbudabham(water } \\
\text { bubbles) }\end{array}$ \\
\hline $\begin{array}{l}\text { Kapha pitta } \\
\text { prakopa }\end{array}$ & $\begin{array}{l}\text { Rakta } \\
\text { Avilata(turbid) }\end{array}$ \\
\hline $\begin{array}{l}\text { Sannipatik } \\
\text { prakopa }\end{array}$ & $\begin{array}{l}\text { Mishra varna, } \text { jeernajwar } \\
\text { sadrush pitam }\end{array}$ \\
\hline
\end{tabular}

Mutra varna Pariksha in different vyadhi:

Shukla varna of mutra is mention in dakmeha, pishtameh and kaphaj pandu. Krishna varna mutra fouds in kalameha, kumbh kamla. Haridra varna mutra is explained in pitta mutrakriccha, kamla, and pitvarn of mutra fouds in pittaj pandu. Neel varna mutra is a diagnostic feature of the neelameh. Rakta varna of mutra is a feature of ashmari, mutrasangh and rakta meha ${ }^{[14][15]}$.

\begin{tabular}{|l|l|}
\hline Mutra varna & Vyadhi \\
\hline Shukla & $\begin{array}{l}\text { Udakameha, pishtameha, } \\
\text { kaphaj pandu }\end{array}$ \\
\hline Krishna & Kalameh, kumbh kamla, \\
\hline Haridra & $\begin{array}{l}\text { Pitta Mutrakriccha, } \\
\text { kamla, ushnavata } \\
\text { mutraghata. }\end{array}$ \\
\hline Pita & Pitta pandu \\
\hline Neel & Neelameh \\
\hline Rakta & $\begin{array}{l}\text { Ashmari, } \\
\text { raktameh. }\end{array}$ \\
\hline
\end{tabular}




\section{Mutra vishesh rupa:}

Sometimes the appearance of mutra provides the diagnostic and prognostic directions in differential diagnosis of the diseases. Avil mutrata i.e. turbidity of urine is diagnostic feature of prameh and Anavil mutrata i.e. clear and transparent appearance of the urine is indication of prameh nivriti which has a prognostic value $^{[16]}$. Accham mutra (Transparent urine) is a important feature of the udakameh, Prasence of sikta(fine granules) in mutra is indication of siktameh, If sandrata(sediments) is present in mutra, it confirms the diagnosis of Sandra meha. Thus on the basis of presence of the sandrata or sikta in mutra we can diagnose the sandrameha or siktameha ${ }^{[17]}$. Mutra having appearance like bhasmodaka(calcium hydroxide/lime water) is feature of the mutrashukrajq Mutrakriccha ${ }^{[18]}$.

\begin{tabular}{|l|l|}
\hline \multicolumn{1}{|c|}{$\begin{array}{c}\text { Mutra rupa(physical } \\
\text { properties) }\end{array}$} & \multicolumn{1}{c|}{ Vyadhi } \\
\hline Avil mutra & Prameh \\
\hline Anavil mutra & Prameh nivriti \\
\hline Accham mutra & Udakameh \\
\hline Sikta in Mutra & Sikta meha \\
\hline Sandrata in mutra & Sandrameh \\
\hline Bhasmodaka pratikash & $\begin{array}{l}\text { Mutrashukra } \\
\text { Mutraghata. }\end{array}$ \\
\hline $\begin{array}{l}\text { Shankh } \\
\text { churnavat/gorochanvat }\end{array}$ & $\begin{array}{l}\text { Mutrasada } \\
\text { Mutraghata }\end{array}$ \\
\hline
\end{tabular}

3. Sparsha Parisha: Freshly collected Mutra should be examine by thermometer to know the Ushana/sheet sparsha(Temp) of mutra. In sheet meha and udak meha the freshly collected urine temp is comparatively less $^{[19]}$. Mutra should also examine by viscometer to know the snigadhata, picchilata, vishada of mutra which has diagnostic use.

\section{Mutra Gandha Pariksha:}

Normal gandha of the mutra is mutragandha(aromatic smell). This can be altered in various disease condition. Nighandha mutra (odorless urine) is present in udakameha ${ }^{[20]}$. Vidgandha mutra is found in Vidvighata Mutraghata $^{[21]}$. Madhugandh mutra is present in madhumeha. Amagandha mutra also found in manjishta meha.

\section{Rasana Pariksha of mutra:}

Acharya Vagbhata has mentioned that varnadi changes in mutra are due to doshdushy samyoga vishesha ${ }^{[22]}$. In context to the prameh Acharya charaka has described that mutre abhidhavantati pipilikasca i.e. crawling of ants towards the urine due to resence of sharkara in mutra (glucose in trine) ${ }^{[23]}$. Amla(acidic) rasa mutra in Amla meha, kshara(alkaline) rasa in kshara meha ${ }^{[24]}$ Madhur(sweet) rasa in madhumeha and ikshumeha are the diagnostic features of the respective prameha.

With help of modern urine chemical examination the rasa of the mutra can be identified by the anumana praman. By urine glucose test we can confirm the madhur rasa, like wise amla rasa and kshara rasa of the mutra can be indentify by the testing the $\mathrm{PH}$ of the urine. If ph less than 7 then it is amla rasa or if the ph of the urine is found more than 7 then it is kshara rasa can be confirmed.

\section{Yogratnakar's Tail Bindu Pariksha:}

Acharya Yogratnakar have described a specialized, scientific and systematic 
method of examination mutra which have a great prognostic value in ayuveda.

Collection of mutra for examination: Vaidya should collect the mutra of the patient for mutra pariksha vidhi before four ghatika in the last yama of the ratri(night). Addyadhara (initial urinary flow) of the mutra should be discarded and mutra from madhyadhara of the patient should collected in a kanch patra(glass dish), kansya patra(bronz dish), mrutta patra (earthan dish) ${ }^{[25]}$.

Method: Mutra pariksha vidhi should be carried out after the sunrise in a natural light on a vidhivata collected urine sample. Mutra should be taken in a kanch patra(glass dish) or kansya patra(bronz dish) or mrutta patra (earthan dish) in a sufficient amount. A drop of till taila is dropped in mutra with the help of trin kashta on the surface of the urine. Then the movement and the behavior of the taib bindu is observed ${ }^{[26]}$.

Prognosis on the basis of movement of the tail bindu: If the taila bindu spreads immediately then vyadhi is sadhya(disease is curable), If the tailbindu does not speads then vyadhi is kashtasadhya(difficult to treat), if the tailbindu sink to bottom then is asadhya(incurable) ${ }^{[27]}$.

\begin{tabular}{|l|l|}
\hline $\begin{array}{l}\text { Movement of the } \\
\text { tailbindu }\end{array}$ & Sadhyasadhyata \\
\hline $\begin{array}{l}\text { Spreads } \\
\text { immediately }\end{array}$ & $\begin{array}{l}\text { Sadhya } \\
\text { vyadhi(curable) }\end{array}$ \\
\hline Dose not spread & $\begin{array}{l}\text { Kashtasadhya } \\
\text { vyadhi(difficult to } \\
\text { treat) }\end{array}$ \\
\hline Sink to bottom & $\begin{array}{l}\text { Asadhya } \\
\text { vyadhi(incurable) }\end{array}$ \\
\hline
\end{tabular}

Prognosis disease can be identify on the basis of direction of the movement of tail bindu on the surface of the mutra ${ }^{[28]}$.

\begin{tabular}{|l|l|}
\hline $\begin{array}{l}\text { Direction of } \\
\text { Movement/spread of tail } \\
\text { bindu }\end{array}$ & $\begin{array}{l}\text { Sadhyasadhy } \\
\text { ata } \\
\text { (prognosis) } \\
\text { of the vyadhi }\end{array}$ \\
\hline $\begin{array}{l}\text { Purva/Paschim/Uttara/Da } \\
\text { kshin }\end{array}$ & $\begin{array}{l}\text { Sukh } \\
\text { Sadhya(curab } \\
\text { le) }\end{array}$ \\
\hline Eshanya & $\begin{array}{l}\text { Death within } \\
\text { one month }\end{array}$ \\
\hline Agneya/Nairutya & $\begin{array}{l}\text { Immediate } \\
\text { death of the } \\
\text { patient }\end{array}$ \\
\hline Vayavya & $\begin{array}{l}\text { Bad } \\
\text { prognosis }\end{array}$ \\
\hline
\end{tabular}

Involvement of the dosha in the samprapti of vyadhi can be identify by tail bindu pariksha it is as follows ${ }^{[29]}$.

\begin{tabular}{|l|l|}
\hline $\begin{array}{l}\text { Shape of the tail } \\
\text { bindu }\end{array}$ & $\begin{array}{l}\text { Dosha involved in } \\
\text { samprapti }\end{array}$ \\
\hline Sarpakara (snake) & Vata \\
\hline $\begin{array}{l}\text { Chatrakara } \\
\text { (umbrella) }\end{array}$ & Pitta \\
\hline Mukta (pearl) & Kapha \\
\hline
\end{tabular}

Prognosis based on different shape of tail bindu is as follows, If the shape of the tail bindu appears as a Hala(axe), kurma(tortoise), sairibha(bufallow), Krand mandala(honey comb), shiroheena nara(head less human body), shastra, khadga(sword), sara(arrow), gatra khanda(body part), mashala patti(spear with masoor dal shape age), laguda(stick) and trichatuspata indicate asadhyata of the vyadhi.

If the shape of the tail bindu appears as hans(swan), karanda(duck), tadoga (dark green pumpkin), kamala 
(lotus), gaja (elephant), Chamara (fan made up of bas grannies used for fly-flap) chatra (umbrella), torana (ornamental door arch), harmya (home) indicative of the sadhya vyadhi.

If the shape of the bindu resembles chalani(sieve), Nara akara(human body), and mastaka dwaya (human body with two head) indicates kuldosha, preta dosha, bhoot dosha respectively ${ }^{[30]}$.

\section{Discussion:}

Dosha, dhatu, mala concept is one of the basic fundamental principle of ayurved. Formation of mala is carried out in intestine. Jatharagni acts on the food and digest it into sara and kitta. Absorbable part of sara which is used for the formation of the dhatu. Unobservable part is kitta is a solid part of the kitta is purisha which is expelled out through purishavaha srotasa. Liquid part goes mutravaha srotasa and called as mutra. So any abnormalities in the processes of Ahara parinama i.e. digestion, absorption, excretion of food can be diagnosed by the mutra pariksha.

As per ayurved perspective diagnosis of disease is depend upon the rogi pariksha and rogpariksha of a patient. Mutra pariksha is used in ayurved practice as a diagnostic and prognostic purpose from thousands year. Mutra pariksha vidhi is one of the important element of the ashtasthana pariksha. Ashtasthana pariksha represents the clinical examinations as well as the laboratory examinations of the mala and mutra pariksha. Mutra pariksha is not elaborated in the brihatrayi systematically but some scatter referenced are available in relation with the physiological and pathological state and in relation with purvarupa and rupa of some diseases. samhita. In samhita kala mutra pariksha was carried out by pratyakshya and anuman praman.

Mutra sangrahan (collection of urine sample) for mutra pariksha should be done before fourth ghatika in the last yama of the ratri. Adyadhara of mutra should be discarded and madhyadhara should be collected in kanch, kansya, mrutika flat dish in a sufficient volume, And the pariksha vidhi should be carried out after the sunrise in a natural light. First morning urine sample is also preferred by modern clinical pathology as it is good representative of the urinary pathology because there is over night collection of the urine in the bladder. By examining the first morning sample even minute pathogens can be identify.

Sushruta's shadavdha priksha i.e. prashne, chakshu, sparsha, shrotra, ghrana, rasana pariksha are useful for the mutra pariksha. Following elements should be incorporated in the mutra pariksha vidhi.

\begin{tabular}{|l|l|}
\hline \multicolumn{1}{|c|}{$\begin{array}{c}\text { Mutra } \\
\text { pariksha }\end{array}$} & \multicolumn{1}{|c|}{ Elements } \\
\hline Prashne & $\begin{array}{l}\text { Vedna, mutra daha, mutra } \\
\text { praman, veg sankhya, } \\
\text { Vibhakta mutra dhara }\end{array}$ \\
\hline Chakshu & $\begin{array}{l}\text { Appearance(bhasmodaka, } \\
\text { gorochana, } \\
\text { shankhchurnavata) varna, } \\
\text { accha, avil, anavil,rakta } \\
\text { puya, varna. }\end{array}$ \\
\hline Sparsha & $\begin{array}{l}\text { Ushana/sheet } \\
\text { sparsha(Temp) of mutra, } \\
\text { snigadhata, picchilata, } \\
\text { vishada. }\end{array}$ \\
\hline
\end{tabular}




\begin{tabular}{|l|l|}
\hline Ghrana & $\begin{array}{l}\text { Madhu, vidgandha, } \\
\text { nirgandha, amagandha. }\end{array}$ \\
\hline Rasana & $\begin{array}{l}\text { Madhur, kshara, amla, } \\
\text { lavana }\end{array}$ \\
\hline $\begin{array}{l}\text { Dosha } \\
\text { vishesh }\end{array}$ & Dosha, Dosha prokopa \\
\hline $\begin{array}{l}\text { Abnormal } \\
\text { constituents }\end{array}$ & $\begin{array}{l}\text { Sarakta, sikta, sandrata, } \\
\text { shakruta,dhatu(shukra, } \\
\text { rakta)vasa, puya, }\end{array}$ \\
\hline $\begin{array}{l}\text { Vyadhi } \\
\text { Vishesh }\end{array}$ & $\begin{array}{l}\text { Vyadhi vishesh rupa related } \\
\text { to mutra. }\end{array}$ \\
\hline Tailbindu & Sadhyasadhyata. \\
\hline
\end{tabular}

While performing the chakshu pariksha we can use microscope for a microscopic examination so that we can rule out the sikta, sandrat(abnormal sediments), blood cells pus cells, epithelial cells etc. For sparsha pariksha we can take help of some modern instruments like for thermometer to know the temp of freshly came out urine, for snigadta we can us the viscometer, to know the rasa of mutra we can use glucose test to know madhur rasa, $\mathrm{PH}$ of urine also help full to know the kshara rasa, Amla rsa, for lavana rasa we used the bile salt and bile pigments. To confirm the presence blood we must perform a benzidine test.

Important work of the standardizing the tail bindu pariksha is being going on at Banarasa Hindu university, Varanasi. They have framed certain criteria regarding standardization of tail bindu pariksha of this as follows.

Morning first urine sample should be taken for test, test should be performed at $1 \mathrm{hr} 36 \mathrm{~min}$ before sunrise, round glass petri dish having 8 inch diameter should be used for test, oil drop of size12 $u l$ should be dropped on urine surface from height 1 $\mathrm{cm}$. Reference value for healthy individual are spread time up to 30 seconds, split time up to $120 \mathrm{sec}$, direction uniform in all direction. In this way tail bindu pariksha are useful to know the prognosis of the disease in a particular patient, and also used to assessment of the healthy person.

\section{Conclusion:}

Ayurveda is science of life which is more based on observations than investigations. Laboratory investigations provides the evidence and confirmation of the diagnosis. In this era of modernization and advancement of the medical science urine examination is widely used for a diagnostic and prognostic purpose. Since ancient time thousands of year back some laboratory investigations(mala, mutra, rakta, shtivan, shukra etc) were available and used while practicing ayurveda. Mutra pariksha vidhi not described systematically in brihat kayi but some scattered references are available. Acharya Yogratnakara has explained the mutra pariksha vidhi in a systematic manner while narrating the ashtasthan pariksh. While examining the urine with a ayurvedic perspective the shadvidha pariksha of the sushruta are useful. Urine should be examine for prashne, chakshu, Shrotro, ghrana, sparsha, rasana. Some medical instruments and techniques are also handy that can be used to assessing mutra by shadavidha pariksha. Tail bindu pariksha is very cost effective technique, can be applied to assessing the prognosis and the severity of the disease to plan a therapeutic measures and it is also handy for the assessment of the healthy condition of the individual. As this is a very vast and big subject further research work is needed in this regard. 


\section{References:}

1. Agnivesha, Charak Samhita Vol1,Charak Chandrika, Hindi commentary by Dr Bramhamanand Tripathi, forwarded by Dr Ganga Sahay Pandey, Chaukhamba Surbharati Prakashan- Varanashi, reprint $6^{\text {th }}$ edition 1999, CharakSutra, Chap.20 Verse20, Page No396.

2. Ibid Agnivesha, Charak Samhita Vol-1, Viman sthan, Chap 8, Vesrse 94, Page No-758.

3. Vagbhata's Ashtanghridyam, Vidyotini Hindi commentary by Kaviraj Atrideva Gupta, edited by Vidya Yadunandan Upadhyaya, Chaukhamba Sanskrit Sansthan, Varanasi, Twelfth edition, Ashatang Hridayam, Sutra, Chap 1 ,Verse 13, page 7.

4. Agnivesha, Charak Samhita Vol2,Charak Chandrika, Hindi commentary by Dr Bramhamanane Tripathi, forwarded by Prabhakar Janardan Deshpande Chaukhamba Surbharati PrakashanVaranashi, reprint edition 2006, Charak-Chikitsa, Chap 15, Verse18-19, Page No 554.

5. Pandit Sharangdharacharya's Sharangdhar Samhita, containing Anjananidana of Maharshi Agnivesha, Dipika Hindi commentary by Bramhanand Tripathi, reprint edition-2007, Sharangdhar Samhita/Purvakhanda/ Chap 5, Verse 13-14, Page no 54.

6. Sushruta's Sushrut Samhita, with the Nibandhasangraha Commentary of Sri Dalhanacharya and The Nyayachandrika Panjika of Sri Gayadasacharya on Nidanasthana, edited by Vaidya Jadavji Trikamji Acharya and Narayan ram Acharya 'Kavyatirtha' Chaukhamba Orientalia, Varanasi, Sushrut Samhita Sutra -chap.10, Verse 4, page no 43.
7. Ibid Vagbhata's Ashtanghridyam, Sharir, Chap 3,Verse 63, page 190.

8. Sri Bhavamishra's Bhavaprakasha, including Bhavaprakasha nighantu, Edited by the Vidyotini hindi commentary, Notes and appendix by Bramhasankara Mishra and Ruplalaji Vaisya, Vol-1, Chaukhamba Sanskrit Bhavan, Varanasi, eleventh edition, Bhavaprakasha/Purvakhand/ verse no 7-8, page no 918.

9. Vangsen Samhita with Hari Hindi commentary by Pandit Hari Prasad Tripathi, Chaukhamba Sanskrit Series, Varanasi, Second edition 2016, Arishtadhikara Chapter 98, Verse 210, page-998.

10. Ibid Sushruta's Sushrut Samhita, chikitsa -chap.12, Verse 20, page no 455.

11. Ibid Agnivesha, Charak Samhita Vol-1, Sharirsthan, Chap 7Verse 15, Page No-927.

12. Sri Madhavakara's Madhava Nidanam, with Madhukosha Sanskirit commentary by Srivijayarakshita and Srikanthadatta with Vidyotini Hidndi commentary and notes by Sri Sudarshana Shastri, Revised and edited by Prof.Yadunandan Upadhyaya, Vol-2, Chaukhambha Sanskrit Sansthan, Varanasi, $19^{\text {th }}$ Edition 1990, Madhav Nidanam, Chapter 33, Verse no-6, Page no 8.

13. Yogratnakara, with Vidyaprabha Hindi commentary by Dr. Indradev Tripathi and Dr.Dayashankar Tripathi, Chaukhamba Krishnadas Academy, Varanasi, Second Edition-2007, YogratnakarAshtavidha Pariksha/ Verse 8,9,10 Page No 9.

14. Ibid Vagbhata's Ashtanghridyam, Nidansthan Chap 10, Verse 8-16, page 254

15. Agnivesha, Charak Samhita Vol-2, Charak Chandrika, Hindi 
commentary by Dr Bramhamanand

Tripathi, forwarded by $\mathrm{Dr}$

Prabhakar Janardan Deshpande,

Chaukhamba Surbharati Prakashan-

Varanashi, reprint edition 2006,

Charak-Chikitsa, Chap 16, Verse 20/34/37, Page No593/595/597.

16. Sushruta's Sushrut Samhita, with the Nibandhasangraha Commentary of Sri Dalhanacharya and The Nyayachandrika Panjika of Sri Gayadasacharya on Nidanasthana, edited by Vaidya Jadavji Trikamji Acharya and Narayan ram Acharya 'Kavyatirtha' Chaukhamba Orientalia, Varanasi, Sushrut Samhita chikitsa -chap.12, Verse 20, page no 455.

17. Vagbhata's Ashtanghridyam, edited with the Vidyotini Hindi commentary by Kaviraj Atrideva Gupta, edited by Vidya Yadunandan Upadhyaya, Chaukhamba Sanskrit Sansthan, Varanasi, Twelth edition, Ashtan Hridyam, Nidan chap 10 Verse 16 page 254 .

18. Sri Madhavkara's Madhav Nidanam, With Sanskrit Commentary Madhukosha by Vijayrakshita \& Srikanthadatta, Edited with Vimala Madhudhara Hindi Commentary and Notes by Dr Bhramhananada Tripathi Vol-1, Chaukhamba Surbharati Prakashan, Varanasi, Reprint edition- 2004, Madhav Nidana Chap 32, Verse 14, Page no 645.
19. Ibid Sri Madhavakara's Madhava Nidanam, Chapter 33, Verse no7,11 Page no 10.

20. Ibid Vagbhata's Ashtanghridyam, Nidansthanm, Chap 10 Verse 8-16 page 254 .

21. Ibid Sri Madhavkara's Madhav Nidanam, Chap 31, Verse 19-20, Page no 634.

22. Vagbhata's Ashtanghridyam, edited with the Vidyotini Hindi commentary by Kaviraj Atrideva Gupta, edited by Vidya Yadunandan Upadhyaya, Chaukhamba Sanskrit Sansthan, Varanasi, Twelth edition, Ashtang Hridyam, Nidan Chap 10, Verse 7, page 254 .

23. Ibid Vagbhata's Ashtanghridyam, Nidan Chap 10, Verse 39 page 256.

24. Vagbhata's Ashtanghridyam, edited with the Vidyotini Hindi commentary by Kaviraj Atrideva Gupta, edited by Vidya Yadunandan Upadhyaya, Chaukhamba Sanskrit Sansthan, Varanasi, Twelth edition AH Nidan 10/14 page 254 .

25. Ibid Yogratnakara, Verse 2, Page No 9.

26. Ibid Yogratnakara, Verse 5, Page No 9.

27. Ibid Yogratnakara, Verse 6, Page No 9.

28. Ibid Yogratnakara, Verse 11-13 Page No 10.

29. Ibid Yogratnakara, Verse 4, Page No 9.

30. Ibid Yogratnakara, Verse 19-20 Page No 10.

Cite article:

A review on mutra pariksha (urine examination) by Ayurvedic perspective.

Sanjay G. Paikrao, Arun S. Dudhamal

Ayurlog: National Journal of Research in Ayurved Science- 2018; (6)(7): 1-9 